\title{
Farklı zemin ve gübre tahliye sitemlerinin bazı süt kalite parametreleri üzerine etkilerinin belirlenmesi
}

\author{
Hakan TAVŞANLI ${ }^{*}$, Nisanur EKTIK ${ }^{2}$, Tevhide Elif GÜNER ${ }^{2}$, Berfin \\ ALTUNDAL $^{2}$, Nisa ÖZKAN ${ }^{2}$ \\ ${ }^{1}$ Balıkesir Üniversitesi, Veteriner Fakültesi, Veteriner Halk sağlı̆̆ Anabilim dalı, Çă̆ış kampüsü, \\ Balıkesir. \\ ${ }^{2}$ Balıkesir Üniversitesi, Sağlık Bilimleri Enstitüsü, Besin Hijyeni ve Teknolojisi Anabilim dalı, ÇağıŞ \\ kampüsü, Balıkesir.
}

Geliş Tarihi (Received Date): 14.04.2021

Kabul Tarihi (Accepted Date): 12.08.2021

$\ddot{O} z$

Kaliteli süt ürünleri üretiminin en önemli hedefi tat ve aroma gibi duyusal kalite kriterlerini koruyarak, gıda güvenliği ve gıda güvencesi kapsamında ürünün muhafaza süresini uzatmaktır. Süt ve süt ürünlerinin raf ömürleri ile tat ve aromalarının gelişimini belirleyen birçok faktör bulunmaktadır. Bu faktörlerden süt ile ilişkili olanlar; süt kompozisyonu, toplam canlı bakteri ve somatik hücre sayısı gibi çiğ süt kalite parametreleridir. Bu kapsamda, bu çalışmada farklı ahır zeminleri ve gübre tahliye sistemlerinin çiğ süt kalite parametreleri üzerine etkileri araştırılmıştır. Beton zemin/ ızgaralı sistem, kauçuk yataklı zemin/ slyırıcıl sistem ve beton zemin/ slyırıcılı sistemlerin ortalama somatik hücre saylları sirasıyla $720.10^{3}$ hücre $/ \mathrm{ml} ; 397.10^{3}$ hücre $/ \mathrm{ml} ; 376.10^{3}$ hücre $/ \mathrm{ml}$, toplam canll bakteri sayllarl ise $135.10^{3} \mathrm{kob} / \mathrm{ml} ; 80.10^{3}$ $\mathrm{kob} / \mathrm{ml} ; 88.10^{3} \mathrm{kob} / \mathrm{ml}$ olarak tespit edilmiştir. Beton zemin/ ızgaralı sistem, kauçuk yatakl zemin/ siytricll sistem ve beton zemin/ slytrıcll sistemlerin ortalama kuru madde değerleri sirasıla \% 12,96; 12,72; 12,82 yă̆ değerleri strasıla \% 3,41; 3,42; 3,46 protein değeri \% 3,23; 3,55; 3,35 ve laktoz değerleri ise strastyla \% 4,92; 4,91; 4,86 olarak belirlenmiştir. Sonuç olarak hayvanların barındırlldı̆̆ ortamların ve özellikle gübre tahliye sistemlerinin çiğ süt toplam canlı bakteri ve somatik hücre saylsı üzerine etkili olduğu görülmüştür. Ayrıca çalışma, ahır zeminlerinin ve gübre tahliye sistemlerinin süt kalite parametreleri üzerine etkilerine yönelik daha detayl çalışmaların yapılmasını işaret etmektedir.

Anahtar kelimeler: Ahır zemin, gübre tahliye sistemleri, somatik hücre sayısl, toplam canlı bakteri saylst.

\footnotetext{
*Hakan TAVŞANLI, tavsanli@balikesir.edu.tr, http://orcid.org/0000-0002-5124-3702

Nisanur EKTiK, nisanurektik@ hotmail.com, http://orcid.org/0000-0001-9389-4362

Tevhide GÜNER, tevhideeliftasci@ gmail.com, http://orcid.org/0000-0002-8706-1417

Berfin ALTUNDAL, altundalberfin98@ gmail.com, http://orcid.org/0000-0002-3153-9362

Nisa ÖZKAN, ozkannisa97@gmail.com, http://orcid.org/0000-0002-0233-4739
} 


\title{
Determining the effects of different barn floor and manure evacuation systems on some milk quality parameters
}

\begin{abstract}
The most important goal of the production of quality dairy products is to extend the storage period of the product within the scope of food safety and security while maintainig the sensory quality criteria such as taste and aroma. There are many factors that determine the shelf life of milk and dairy products and the development of their taste and aroma. Among these factors, those associated with milk; milk composition are raw milk quality parameters such as total viable bacteria and somatic cell count. In this context, the effects of different barn floor types and manure disposal systems on raw milk quality parameters were examined in this study. Average sometic cell count of the concrete floor / grid system, rubber bed floor / scraper system and concrete floor / scraper system were determined as respectively $720.10^{3}$ cells $/ \mathrm{ml}$; $397.10^{3} \mathrm{cells} / \mathrm{ml} ; 376.10^{3} \mathrm{cell} / \mathrm{ml}$, and total viable bacteria numbers were determined as respectively $135.10^{3} \mathrm{cfu} / \mathrm{ml} ; 80.10^{3} \mathrm{cfu} / \mathrm{ml}$ and $88.10^{3} \mathrm{cfu} / \mathrm{ml}$. The average dry matter values of the concrete floor / grid system, rubber bed floor / scraper system and concrete floor / scraper system were determined as, 12.96, 12.72, 12.82 ; oil values were determined as 3,41, 3,42, 3,46; protein values determined as 3.46, 3.55, 3.35 and lactose values were determined as 4.92, 4.91 and 4.86 respectively. As a result, it has been determined that the environments where the animals live and especially the manure disposal systems, are effective on the raw milk total viable bacteria and sometic cell count values. In addition, more detailed studies on the effects of barn floors and manure disposal systems on milk quality parameters are recommended in this study.
\end{abstract}

Keywords: Barn floor, manure evacuation systems, somatic cell count, total viable bacteria count.

\section{Giriş}

Süt; dişi memeli hayvanların yavrularının kendi kendisini besleyecek duruma gelinceye kadar almak zorunda olduğu besin maddelerinin tümünü içeren bir vücut salgısıdır. Meme bezlerinden hayvan türüne göre farklı sürelerde salgılanan, porselen beyazı (krem-beyaz) renginde, kendine has tat ve kokusu olan bir sivı olarak tanımlanmaktadır [1]. Bu biyolojik sıvının sağlıklı ve kaliteli olması; süt miktarı, sütteki yağ ve protein değerleri, toplam canlı bakteri (TCB) ve somatik hücre sayısı (SHS) gibi parametrelerle izlenebilir [2-4]. Bu faktörlerden TCB ve SHS, meme sağlığı ve sütün kalitesini belirlemede güvenilir bir ölçüt olarak kullanılmaktadır. Aynı zamanda süt fiyatının belirlenmesinde ve üreticiye prim sağlanmasında da etkili faktörlerdir [3, 5]. Sütün TCB sayısını; meme dokusu, ahır koşulları, personel ve çevresel birçok faktöre bağlı olarak bulaşan patojen ve apatojen bakteriler ile maya ve küf gibi mikroorganizmalar oluşturmaktadır [6]. SHS ise sütte bulunan; epitel hücreler, epitel hücre döküntüleri, eritrositler, plazma hücreleri ve lökositlerden oluşmaktadır. SHS'deki artış, süt veriminde \% 20'ye kadar varan kayıplara neden olmaktadır [7]. Yüksek SHS yalnızca süt verimini değil, aynı zamanda süt bileşimini ve kalitesini de olumsuz etkilemektedir [8]. Bunun yanı sıra yüksek TCB ve SHS insanlarda; Brucella spp., Listeria monocytogenes, Escherichia coli, Staphylococcus aureus, Mycobacterium bovis ve 
Coxiella burnettii kaynaklı gıda enfeksiyonlarının görülme sıklığını arttırabilir [9, 10]. SHS; ineğin yaşı, laktasyon evresi, stres, mevsim, ahırın yerleşim planı, ahır ve durak zemini, beslenme ve mastitis gibi faktörlere bağlı olarak değişmektedir [3, 11-13]. Bu faktörlerden özellikle meme sağlı̆̆ ile ilişkilendirilen TCB ve SHS çiğ sütün kalitesini belirlemek amacı ile sınıflandırılmışlardır. $\mathrm{Bu}$ sınıflandırmaya göre sağlıklı hayvanlardan sağılan sütün toplam bakteri sayısı 1000-100.000 kob/ ml değerleri arasında yer almaktadır [14]. Somatik hücre sayısı ise $10^{5}$ hücre/ $\mathrm{ml}$ düzeyinde ve yaklaşık \%50 epitel hücresi ve \%50 lökosit şeklindedir $[15,16]$. Genellikle memenin bir lobunda mastitis varlığını işaret eden SHS değerinin $2 \times 10^{5}$ hücre/ ml'nin üzerinde olduğu bildirilmiştir $[15,17]$. SHS artışına paralel olarak TCB da artış olması bu iki parametrenin mastitisin tanımlanmasında temel kriter kabul edilmesini sağlamaktadır [18]. Çiftliklerde yapılacak hayvan refahını iyileştirme uygulamaları, bu iki parametrede azalmaya neden olabilir.

Çiğ süt kalite faktörlerini (TCB ve SHS) etkileyen bakım, rasyon, iklim ve hayvanlara uygulanan davranış gibi birçok faktör bulunmaktadır. Bununla beraber, hayvan barınaklarında zeminin durumu ve gübre tahliye sistemleri, hayvanlarda ayak/tınak travmalarını ve ortamın hijyenik kalitesini belirleyen önemli bir unsur olarak karşımıza çıkmaktadır. Bu amaçla çalışmamızda hayvanların yatak, gezinme alanları ve gübre tahliye sistemlerini kapsayan barınak zeminlerinin TCB ve SHS'ye etkisinin araştırılması amaçlanmıştır.

\section{Materyal ve Metot}

\subsection{Süt örneklerinin toplanmast}

Üç farklı ahır zemini/ sistemine sahip bir çiftlikten örnekler toplandı. Çiftlikteki hayvanların \%15,8'i (53/336) beton zemin/ 1zgaralı sisteme, \%34,2'si (115/336) kauçuk yataklı zemin /sıyricilı sisteme ve \%50'si (168/336) ise beton zemin/ siyırıcılı sisteme sahipti. SHS ve süt kompozisyonu için; otomatik sağım ünitesine entegre Cleaning In Place sistemine (CIP) sahip ve süt numune alma aparatı bulunan çiftlikten 15 gün ara ile 2 defa ziyaret edilip toplam 336 hayvandan 672 süt örneği alındı. TCB sayısı analizi için meme dokusu tek kullanımlık kâğıt havlular ile temizlendikten sonra memenin süt kanalındaki ilk sağım sütü döküldü. Ardından meme \%70 etanol ile dezenfekte edilerek steril $100 \mathrm{ml}$ kaplara 4 meme lobundan $20 \mathrm{ml}$ süt örneği alınd. Steril süt örneği kaplarına koruyucu tablet (Mikrotabs $\left.{ }^{\circledR}\right)$ atıldı. Örnekler soğuk zincir altında laboratuvara getirilerek analizlere başlandi.

\subsection{Somatik hücre sayısı ve toplam canlı bakteri sayısı analizi}

Süt örneklerinin SHS ve kimyasal kompozisyonu, Combi FTS (Bentley $\left.{ }^{\circledR}, A B D\right)$ süt analizatörü kullanılarak tespit edildi. TCB analizi ise EN-ISO 4833-1: 2013 ve 4833-2: 2013 referans değerlerinde ölçüm yapan sertifika no: 2013LR44 Bacto Count IBC $\left(\right.$ Bentley $\left.^{\circledR}, A B D\right)$ süt analizatörü kullanılarak tespit edildi. SHS ve TCB analizi için kullanılan süt analizatörleri ortak çalışama protokolü kullanır. Bu protokolde bakteriyel hücre sayımında farklılıklar olmakla birlikte temel olarak hücreler proteolitik enzimler ile yıkımlanır. Açığa çıkan DNA floresan 1şıldama yapan boya ile boyanır ardından boyanan hücre DNA'ları akış sitometrisi tabanlı lazer sayıcı tarafından saptanır. TCB analizindeki farklılık ise hücre yıkımlanmasını hızlandırmak için $50{ }^{\circ} \mathrm{C}$ de 10 dakika inkubasyon süresi içerisinde 30 saniye boyunca 2 defa sonikasyon işlemi uygulanmaktadir. 


\subsection{Istatistiksel analiz}

Çalışmada gruplar arasında farklılığın tespitinde SPSS 25 istatistik paket programı kullanıld1. Veriler ortalama \pm standart sapma olarak ifade edildi. Verilerin normal dağılım gösterip göstermediği Kolmogorov Smirnov testi ile değerlendirildi. Gruplar arası farklılık Kruskal- Wallis testi ile değerlendirilirken iki grup arasındaki farklılıkların değerlendirilmesinde Turkey-HSD testi kullanıldı.

\section{Sonuçlar}

Çalışmamızda beton zemin/ ızgaralı sistem, kauçuk yataklı zemin/ sıyırıcılı sistem ve beton zemin/ sıyırıcılı sistemlerin TCB ve SHS üzerine etkisi araştırıldı. SHS bakımından beton zemin/ siyırıcılı sistem ile diğer zeminler arasında istatistiksel olarak fark tespit edildi $(p<0,01)$. En düşük SHS beton zemin/ sıyırıcılı sistemde $376 \times 10^{3}$ hücre/ ml olarak belirlendi. En yüksek SHS beton zemin/ 1zgaralı sistemde $720 \times 10^{3}$ hücre/ $\mathrm{ml}$ olarak belirlendi. TCB sayısında ise zeminler arasında istatistiksel olarak fark tespit edilmedi $(\mathrm{p}>0,05)$. En yüksek TCB sayısı SHS'de olduğu gibi beton zemin/ 1zgaralı sistemde $1,3 \times 10^{5} \mathrm{kob} / \mathrm{ml}$ olarak belirlendi. Sütün kuru madde değeri bakımından kauçuk zemin/ sıyırıcılı sistem ile diğer zeminler arasında istatistiksel olarak fark tespit edildi $(\mathrm{p}<0,01)$. Sütün yă değeri bakımından zemin ve sistemler arasında istatistiksel olarak fark tespit edilmedi $(p>0,05)$. Sütün protein değeri bakımından tüm zemin ve sistemlerin birbirinden farklı olduğu saptandı $(p<0,01)$. Sütün laktoz değeri bakımından ise beton zemin/ 1zgaralı sistem ile beton zemin/ siyırıcilı sistem arasında istatistiksel olarak fark tespit edilirken $(p<0,01)$, beton zemin/ 1zgaralı sistem ile kauçuk zemin/ sıyırıcılı sistemin birbirine benzer olduğu görüldü (Tablo 1).

Tablo 1. Süt örneklerinin somatik hücre sayısı, toplam bakteri sayıs1 ve kompozisyonu

\begin{tabular}{|c|c|c|c|}
\hline Parametreler & $\begin{array}{c}\text { Beton/ Izgara } \\
(\mathrm{n}=53) \\
\text { Ortalama/ Standart } \\
\text { hata }\end{array}$ & $\begin{array}{l}\text { Kauçuk yatakl1/ Siyırıcılı } \\
\qquad(\mathrm{n}=115) \\
\text { Ortalama/Standart hata }\end{array}$ & $\begin{array}{c}\text { Beton/ Siyırıcılı } \\
(\mathrm{n}=168) \\
\text { Ortalama/ Standart } \\
\text { hata }\end{array}$ \\
\hline SHS (hücre/ml) & $720.10^{3} / 135.10^{3 \mathrm{bc}}$ & $397.10^{3} / 84.10^{3 b}$ & $376.10^{3} / 82.10^{3 a}$ \\
\hline TCB (kob/ml) & $135.10^{3} / 27.10^{3 \mathrm{a}}$ & $80.10^{3} / 11.10^{3 \mathrm{a}}$ & $88.10^{3} / 9.10^{3 a}$ \\
\hline Kuru madde (\%) & $12,96 / 0,07^{\mathrm{a}}$ & $12,72 / 0,01^{\mathrm{c}}$ & $12,82 / 7,95^{\mathrm{ab}}$ \\
\hline Yağ (\%) & $3,41 / 0,04^{\mathrm{a}}$ & $3,42 / 0,03^{\mathrm{a}}$ & $3,46 / 0,02^{\mathrm{a}}$ \\
\hline Protein $(\%)$ & $3,23 / 0,03^{\mathrm{a}}$ & $3,55 / 0,02^{\mathrm{b}}$ & $3,35 / 0,03^{\mathrm{c}}$ \\
\hline Laktoz (\%) & $4,92 / 0,01^{\mathrm{a}}$ & $4,91 / 0,01^{\mathrm{ab}}$ & $4,86 / 0,01^{\mathrm{c}}$ \\
\hline
\end{tabular}

\section{Tartışma}

TCB sayısında artış ve bunu izleyen yüksek SHS sayısı sütte ve ürünlerinde ekşime, acılık, oksidasyon ve burukluk gibi duyusal bozukluklara ve teknolojik kusurların oluşumuna neden olmaktadır. Gelişen duyusal bozukluklar çiğ sütteki yüksek bakteri sayısına bağlı olarak pastörizasyondan sonra aktivitesini devam ettiren bakteriyal enzimlerin etkisi ile oluşan proteoliz ve lipoliz olayı ile meydana gelmektedir. Bu iki 
kimyasal reaksiyon sadece bakteriyel enzimlerle değil aynı zamanda sütün kendi yapısında bulunan endojen kaynaklı enzim aktiviteleri ile de gerçekleştirilmektedir. Çiğ sütteki bakteri sayısı düşük olduğunda $(<25,000 \mathrm{kob} / \mathrm{ml})$, süt aromasını değiștiren tek etken sütün endojen enzimlerine bağlı gerçekleşen kimyasal reaksiyonlardır. Çiğ sütteki TCB ve SHS sayısındaki artış, pastörize ve UHT sütlerde istenmeyen tat oluşumuna neden olmaktadır [19-21]. SHS'ye bağlı olarak özellikle lizozim, laktoperoksidaz, NAGaz ve plazmin enzimlerinin seviyelerinde artışların olduğu bildirilmiştir [22-24]. Yüksek SHS'ye sahip pastörize sütte, serbest yağ asitlerindeki artış lipolizin etkisini, küçük hidrofobik peptitlerin birikimi ise proteolizin etkisini kanitlar niteliktedir [25-28]. Yoğurtlarda ise yüksek TCB ve SHS daha çok ürünün raf ömrünün kısalması ve duyusal özelliklerde bozuklukların oluşumu ile karakterizedir [29]. Bunun yanı sıra yüksek SHS yoğurtların viskozitesinde azalmaya neden olmaktadır [30]. Yoğurt ve diğer fermente süt ürünlerinde yüksek SHS, laktik asit bakterilerinin metabolik faaliyetlerinde azalma ya da artmaya neden olmaktadır [31].

Süt bileşimi ve konsantrasyonunu; hayvanın cinsi, yaşı, laktasyon dönemi, iklim, beslenme, barınak ve hayvan refahı gibi birçok faktör etkilemektedir. Süt bileşimi içerisinde yer alan TCB ve SHS ise sütün hijyeni, bakım besleme ve hayvan refahının önemli bir göstergesi olup hayvanların barındığı ahır ve ahır zeminlerinden etkilenmektedir. Özellikle bu şartlar sığırlar için günlük sürelerinin yaklaşık \%50'sini oluşturan yatma davranışının değişmesine neden olmaktadır $[32,33]$. Yeterli dinlenme süresi; ayaklarda azalmış stres, azalmış topallık, artan beslenme aktivitesi, artan geviş getirme aktivitesi ve meme sağlığı ile ilişkilendirilir [34-36]. Buna bağlı olarak çiftliklerde ahır zeminleri; kauçuk, taş, çakıl, tuğla, beton ve şilte gibi farklı tiplerde tercih edilmektedir. Kötü tasarlanmış durak ve yatak tesisleri, dinlenme safhasında azalma, kötü hijyen skoru ve bunun sonucunda meme sağlığında bozulmaya neden olmaktadır [37]. Yapılan literatür taramalarında zemin yapısının ve gübre tahliye sisteminin TCB ve SHS ile süt kompozisyonuna etkisinin araştırıldığı çok kısıtlı sayıda çalışma bulunmaktadır. Bu çalışmaların birinde Sadharakiya ve Sorathiya [38] çalışmamızdan farklı olarak SHS'nin kauçuk yataklı zeminlerde (165454 hücre/ml), beton zemin/ siyırıcılı sisteme göre (190201 hücre/ $\mathrm{ml}$ ) daha düşük olduğunu bildirmişlerdir. Aynı zamanda çalışmamızda beton zeminde ve 1zgaralı sistemde bulunan hayvanların SHS (720.000 hücre/ml), beton zemin ve siyırıcılı sistemde (326.000 hücre/ml) bulunanlara göre çok daha yüksek tespit edildi. Bu durum TCB ve SHS'de zeminin yapısından çok ortamdan gübreyi tahliye edecek olan sistemlerin daha etkili olduğu varsayımı çıkarılabilir [39, 40]. Can ve ark. [41] yaptıkları çalışmada 1zgara sisteminin işletmelerde kötü refah ortamı ve düşük hijyen skoru oluşumuna neden olduğunu bildirmişlerdir. $\mathrm{Bu}$ bulgular çalışmamızda aynı zemin (beton) özelliklerine sahip ancak 1zgaralı sistemde barınan hayvanlarda daha yüksek TCB ve SHS verilerini doğrular niteliktedir. Bununla beraber Rowbotham ve ark. [42] inorganik materyallerden oluşan zeminlerde barınan hayvanlarda TCB ve SHS'nin düşük olduğunu bildirmişlerdir. Bu bulgu çalışmamız ile TCB sayısı yönünden benzer ancak somatik hücre sayısının yüksek olması yönüyle farklılık göstermektedir. Zemin ve gübre tahliye sistemlerinin kuru madde üzerine etkisinin incelendiği bir çalışmada Sadharakiya ve Sorathiya [38] bulgularımızdan farklı olarak, SHS düşük olan zemindeki hayvanlara ait sütlerin, kuru madde değerinin daha yüksek olduğunu bildirmişlerdir. SHS ile süt kompozisyonu arasındaki ilişkiyi araştıran birçok çalışma bulunmaktadır. Bu araştırmaların bazılarında çalışmamıza benzer olarak SHS ile kuru madde arasında paralel bir bağlantı [43] tespit edilirken birçok çalışmada ters yönde bir bağlantı olduğu bildirilmiştir [44-46]. Önal ve Özder [47] SHS ile protein düzeyi 
yönünden çalışmamızdan farklı olarak paralel bir bağlantı olduğunu rapor etmiş̧lerdir. Özlem ve Kul [48] yaptıkları çalışmada meme içi enfeksiyona bağlı SHS yüksek sütlerde laktoz seviyesinde azalmanın olduğunu bildirmişleridir. Çalışmamızda ise SHS yüksek olan beton zemin/ 1zgara siteminde barınan hayvanların sütlerinde laktoz daha yüksek oranda belirlenmiştir. Bunun sebebi çalışmamızda örneklerin alındığı hayvanlarda klinik olarak mastitis belirtilerinin görülmemesi ve SHS göre subklinik değerlendirilen hayvanlarda ise meme içi enfeksiyonun şiddetinin farklılığından kaynaklanabileceği düşünülmektedir.

Sonuç olarak; literatür bilgilerinin 1şığında süt ürünlerinin raf ömrü ile tat ve aromasının gelişiminde önemli olan TCB ve SHS değerlerinin, hayvanların barındırıldığı ortamın refahı ve hijyeni ile yakın ilişki içerisinde olduğu tespit edilmiştir. Aynı zamanda çalışmamızda zemin yapısının yanında gübre tahliye sistemlerinin de sütün bu iki önemli kalite parametresi üzerine etkili olduğu belirlenmiştir. Yapılan çalışmalar zemin ve gübre tahliye sistemlerinin daha çok hayvan refahı, topallık, dinlenme aralıkları ve stres hormon düzeyleri üzerine etkilerine odaklanmıştır. Çalışmamız zemin ve gübre tahliye sistemlerinin TCB ve SHS üzerine etkisinin olduğu göstererek bu alanda daha detaylı çalışmaların yapılmasına yönelik ihtiyacı işaret etmektedir.

\section{Kaynaklar}

[1] Metin, M. Süt teknolojisi sütün bileşimi ve işlenmesi. Ege Üniversitesi Mühendislik Fakültesi Yayınları No: 33, Baskı: 6, Ege Üniversitesi Basımevi, Bornova - İzmir, 66-69, (2005).

[2] Lievaart, J.J., Barkema, H.W., Kremer, W.D.J., Van Den Broek J.,Verheijden, J.H.M. ve Heesterbeek, J.A.P., Effect of herd characteristics, management practices, and season on different categories of the herd somatic cell count, Journal of Dairy Science, 90, 4137-4144, (2007).

[3] Raubertas, R. F. ve Shook, G. E., Relationship between lactation measures of somatic cell concentration and milk yield, Journal of Dairy Science, 65, 3, 419425, (1982).

[4] Shook, G. E., Selection for disease resistance, Journal of Dairy Science, 72, 5, 1349-1362, (1989).

[5] Yıldırım, H., Çimen, M., İlhan, A., Turan, Z., Demir, Z. ve Demir, B., Adıyaman ilinden elde edilen inek sütlerinde ekonomik öneme sahip biyokimyasal parametrelerin $\mathrm{Ab}$ ve Türk standartlarına uygunluklarının belirlenmesi, İstanbul Aydın Üniversitesi Dergisi, 6, 22, 1-7, (2014).

[6] Günhan, T., Demir, V. ve Bilgen, H., Çiftlik tipi süt soğutma tanklarının performans değerlerinin deneysel olarak belirlenmesi, Tarım Makinaları Bilimi Dergisi, 2, 4, 369-379, (2006).

[7] Mukherjee, J., Chaudhury, M. ve Dang, A.K., Alterations in the relative abundance of haptoglobin $(\mathrm{Hp})$ transcripts in total milk somatic cells during different stages of lactation cycle in high yielding cross-bred cows, Biological Rhythm Research, 48, 577-581, (2017).

[8] Cinar, M., Serbester, U., Ceyhan, A. ve Gorgulu, M., Effect of somatic cell count on milk yield and composition of first and second lactation dairy cows, Italian Journal of Animal Science, 14, 1, 3646, (2015). 
[9] David, S. D., Raw milk and the first amendment: Implications for public health policy and practice, Public Health Reports, 129, 5, 455-457, (2014).

[10] Maldonado, Y. A., Glode, M. P., Bhatia, J., Brady, M. T., Byington, C. L., Davies, H. D. ve Schwarzenberg, S. J., Consumption of raw or unpasteurized milk and milk products by pregnant women and children, Pediatrics, 133, 1, 175-179, (2014).

[11] Jones, G. M., Pearson, R. E., Clabaugh, G. A. ve Heald, C. W., Relationships between somatic cell counts and milk production, Journal of Dairy Science, 67, 8, 1823-1831, (1984).

[12] Cedden, F., Kor, A. ve Keskin, S., Laktasyonun geç döneminde keçi sütünde somatik hücre sayımı; yaş, süt verimi ve bazı meme özellikleri ile olan ilişkileri, Yüzüncü Yıl Üniversitesi Tarım Bilimleri Dergisi, 12, 2, 63-67, (2002).

[13] Eyduran, E., Özdemir, T., Yazgan, K. ve Keskin, S., Siyah Alaca inek sütündeki somatik hücre sayısına laktasyon sırası ve dönemin etkisi, Yüzüncü Yıl Üniversitesi Veteriner Fakültesi Dergisi, 16, 1, 61-65, (2005).

[14] Boor, K. J., Brown, D. P., Murphy, S. C., Kozlowski, S. M. ve Bandler, D. K., Microbiological and chemical quality of raw milk in New York State, Journal of Dairy Science, 81, 6, 1743-1748, (1998).

[15] Kelly, A. L., Leitner, G. ve Merin, U., Milk quality and udder health: Test methods and standards, (2018).

[16] Panthi, R. R., Jordan, K. N., Kelly, A. L. ve Sheehan, J. D., Selection and treatment of milk for cheesemaking in Cheese, Academic Press, 23-50, (2017).

[17] Alhussien, M. N. ve Dang, A. K., Milk somatic cells, factors influencing their release, future prospects, and practical utility in dairy animals: An overview, Veterinary World, 11, 5, 562, (2018).

[18] Hegde, R., Isloor, S., Prabhu, K. N., Shome, B. R., Rathnamma, D., Suryanarayana, V. V. S., ve Hegde, N. R., Incidence of Subclinical mastitis and mastitis prevalence of Major Pathogens of Organized and Unorganized Sectors Farms, Indian Journal of Microbiology 53, 315-320, (2013).

[19] Barbano, D. M., Ma, Y. ve Santos, M. V., Influence of raw milk quality on fluid milk shelf life, Journal of Dairy Science, 89, 15-19, (2006).

[20] Fernandes, A. M., Moretti, T. S., Bovo, F., Lima, C. G. ve Oliveira, C. A., Effect of somatic cell counts on lipolysis, proteolysis and apparent viscosity of UHT milk during storage, International Journal of Dairy Technology, 61, 4, 327332, (2008).

[21] Santos, M. V., Ma, Y. ve Barbano, D. M., Effect of somatic cell count on proteolysis and lipolysis in pasteurized fluid milk during shelf-life storage, Journal of Dairy Science, 86, 8, 2491-2503, (2003).

[22] Grönlund, U., Hultén, C., Eckersall, P. D., Hogarth, C. ve Waller, K. P., Haptoglobin and serum amyloid $\mathrm{A}$ in milk and serum during acute and chronic experimentally induced Staphylococcus aureus mastitis, The Journal of Dairy Research, 70, 4, 379, (2003).

[23] Somers, J. M., O'Brien, B., Meaney, W. J. ve Kelly, A. L., Heterogeneity of proteolytic enzyme activities in milk samples of different somatic cell count, The Journal of Dairy Research, 70, 1, 45, (2003).

[24] Urech, E., Puhan, Z. ve Schällibaum, M., Changes in milk protein fraction as affected by subclinical mastitis, Journal of Dairy Science, 82, 11, 2402-2411, (1999). 
[25] Ma, Y., Ryan, C., Barbano, D. M., Galton, D. M., Rudan, M. A. ve Boor, K. J., Effects of somatic cell count on quality and shelf-life of pasteurized fluid milk, Journal of Dairy Science, 83, 2, 264-274, (2000).

[26] Shipe, W. F. ve Senyk, G. F., Effects of processing conditions on lipolysis in milk, Journal of Dairy Science, 64, 11, 2146-2149, (1981).

[27] Lemieux, L. ve Simard, R. E., Astringency, a textural defect in dairy products, Le Lait, 74, 3, 217-240, (1994).

[28] O'Brien, B., Meaney, W.J., McDonagh, D. ve Kelly, A., Influence of somatic cell count and storage interval on composition and processing characteristics of milk from cows in late lactation, Australian Journal of Dairy Technology, 56, 213218, (2001).

[29] Oliveira, C. A. F., Fernandes, A. M., Neto, O. C. C. ve Fonseca, L. F. L., Composition and sensory evaluation of whole yogurt produced from milk with different somatic cell counts, Australian Journal of Dairy Technology, 57, 3, 192, (2002).

[30] Fernandes, A. M., Oliveira, C. A. ve Lima, C. G., Effects of somatic cell counts in milk on physical and chemical characteristics of yoghurt, International Dairy Journal, 17, 2, 111-115, (2007).

[31] Le Maréchal, C., Thiéry, R., Vautor, E. ve Le Loir, Y., Mastitis impact on technological properties of milk and quality of milk products-a review, Dairy Science \& Technology, 91, 3, 247-282, (2011).

[32] Dechamps, P., Nicks, B., Canart, B., Gielen, M. ve Istasse, L., A note on resting behaviour of cows before and after calving in two different housing systems, Applied Animal Behaviour Science, 23, 1-2, 99-105, (1989).

[33] Krohn, C. C. ve Munksgaard, L., Behaviour of dairy cows kept in extensive (loose housing/pasture) or intensive (tie stall) environments II. Lying and lying-down behaviour, Applied Animal Behaviour Science, 37, 1, 1-16, (1993).

[34] Metcalf, J. A., Roberts, S. J. ve Sutton, J. D., Variations in blood flow to and from the bovine mammary gland measured using transit time ultrasound and dye dilution, Research in Veterinary Science, 53, 1, 59-63, (1992).

[35] Rulquin, H. ve Caudal, J. P., Effects of lying or standing on mammary blood flow and heart rate of dairy cows, In Annales de Zootechnie 41, 1, 101, (1992).

[36] Grant, R. J., Incorporating dairy cow behavior into management tools, (2004). http://www.milkproduction.com/Library/Scientific-articles/Animal welfare/Incorporating-dairy-cow-/, (19.03.2021).

[37] Cook, N. B., Bennett, T. B. ve Nordlund, K. V., Effect of free stall surface on daily activity patterns in dairy cows with relevance to lameness prevalence, Journal of Dairy Science, 87, 9, 2912-2922, (2004).

[38] Sadharakiya, K. ve Sorathiya, L., Effects of rubber mat flooring on behaviours, welfare and production performance in crossbred cows, International Journal of Livestock Research, 9, 1, 195-201, (2019).

[39] Magnusson, M., Herlin, A. H. ve Ventorp, M., Effect of alley floor cleanliness on free-stall and udder hygiene, Journal of Dairy Science, 91, 10, 3927-3930, (2008).

[40] DeVries, T. J., Aarnoudse, M. G., Barkema, H. W., Leslie, K. E. ve Von Keyserlingk, M. A. G., Associations of dairy cow behavior, barn hygiene, cow hygiene, and risk of elevated somatic cell count, Journal of Dairy Science, 95, $10,5730-5739,(2012)$. 
[41] Can S., Meral H., Göncü S., Görgülü M., Süt sı̆̆ırcılı̆̆g işletmelerinde sürü yönetim kontolü, Ulusal Zootekni Öğrenci Kongresi. Atatürk Üniversitesi, (2013).

[42] Rowbotham, R. F. ve Ruegg, P. L., Association of bedding types with management practices and indicators of milk quality on larger Wisconsin dairy farms, Journal of Dairy Science, 98, 11, 7865-7885, (2015).

[43] Gökçe, G., Çukurova Bölgesi entansif süt sığırı işletmelerindeki ilkine doğuran siyah alacalarda somatik hücre sayısına etki eden bazı tip, sağım ve amanejman özelllikleri arası ilişkiler, Doktora Tezi, Çukurova Üniversitesi, Fen Bilimleri Enstitüsü, Adana, (2011).

[44] Emanuelson, U., Danell, B. ve Philipsson, J., Genetic parameters for clinical mastitis, somatic cell counts, and milk production estimated by multiple-trait restricted maximum likelihood, Journal of Dairy Science, 71, 2, 467-476, (1988).

[45] Schutz, M. M., Hansen, L. B., Steuernagel, G. R. ve Kuck, A. L., Variation of milk, fat, protein, and somatic cells for dairy cattle, Journal of Dairy Science, 73, 2, 484-493, (1990).

[46] Aytekin, İ. ve Boztepe, S., Süt Sığırlarında Somatik Hücre Sayısı, Önemi ve Etki Eden Faktörler, Türk Tarım- Gıda Bilim ve Teknoloji Dergisi, 2, 112-121, (2014).

[47] Önal, A.R. ve Özder, M., Trakya'da özel bir süt işleme tesisi tarafindan değerlendirilen çiğ sütlerin somatik hücre sayısı ve bazı bileşenlerinin tespiti, Tekirdağ Ziraat Fakültesi Dergisi, 4, 2, 195- 199, (2007).

[48] Özlem, O. ve Ertuğrul, K. U. L., Effects of some environmental factors on somatic cell count and milk chemical composition in cow bulk tank milk. Akademik Ziraat Dergisi, 9(1), 163-170, (2020). 